\title{
Pozen pomladanski mraz in sneg v maju 2012 je pomrznil mlade bukove liste in spodbudil razvoj bolezni rjavenja bukovih listov na Snežniku
}

\author{
Nikica OGRIS ${ }^{1 *}$, Iztok SINJUR ${ }^{1}$, Frenk PRELEC ${ }^{2}$
}

Ob koncu prve in $\mathrm{v}$ začetku druge dekade maja 2012 so bile v Sloveniji po podatkih Državne meteorološke službe dnevne temperature zraka občutno nad dolgoletnim povprečjem obdobja 1961-1990 (Cegnar, 2012). Po nižinah se je živo srebro v omenjenem obdobju najvišje povzpelo 12. maja 2012, ko so na nekaterih uradnih meteoroloških postajah zabeležili $30{ }^{\circ} \mathrm{C}$ in več. V noči na 13. maj 2012 je Slovenijo od severozahoda dosegla hladna fronta s padavinami in ohladitvijo, ki je bila na nekaterih uradnih meteoroloških postajah najizrazitejša do sedaj (Urad za meteorologijo, 2012). V teden dni trajajočem občutno hladnejšem obdobju je 16. maja sledila še ena ohladitev s padavinami (slika 1). Ob obeh vremenskih poslabšanjih je dež ponekod na Notranjskem prešel v sneg vse do nižin, lokalno, zlasti v mraziščih, pa so se nato zlasti ob jutrih več dni zapored pojavljale zelo nizke temperature zraka (slika 1).

Na območju Snežnika je v obeh vremenskih poslabšanjih dež prešel v sneg do okoli 700 m nadmorske višine. Opazovalec na uradni meteorološki postaji Mašun (1023 m), severozahodno od Snežnika, je sneženje beležil tako 13. kot 16. maja, 17. maja 2012 ob 8. uri pa je izmeril $2 \mathrm{~cm}$ debelo snežno odejo. Na uradni meteorološki postaji Babno Polje (754 m) je snežilo le 16. maja 2012 (Meteorološki arhiv ARSO, 2012). Glede na podatke uradnih meteoroloških postaj in samodejno meteorološko postajo Slovenskega meteorološkega foruma v Veliki Padežnici (4 km od prizadetega območja), se je v času padavin, 13. in 16. maja 2012, temperatura zraka na območju poškodb gibala okoli ledišča (slika 2). Glede na omenjene podatke o temperaturah in zapadlem snegu sklepamo, da je na prizadetem območju v času 13.-17. maja 2012 padlo 5 do $10 \mathrm{~cm}$ snega, ki ga je spremljala tudi zmrzal. Nizke temperature in sneg sta bila primarni vzrok za poškodbe mladih bukovih listov na širšem območju Snežnika in drugod po Sloveniji. Vremenski dogodek je spremljal tudi veter, ki je sorazmeroma hitro odpihnil sneg z že olistanih bukev, kar je preprečilo obsežno lomljenje vej.

V listju navadne bukve (Fagus sylvatica L.) se gliva Apiognomonia errabunda (Roberge ex Desm.) Höhn. (anamorf Discula umbrinella (Berk. \& Broome) M. Morelet) pojavlja kot endofit, ne da bi povzročala bolezenska znamenja (Maček, 2008). Gliva postane patogena šele, če je listje izpostavljeno stresu. Pozen pomladanski mraz v maju 2012 je povzročil stres mladim listom bukve na Snežniku. To je bil razlog, da je endofitna gliva Apiognomonia errabunda postala patogena in začela povzročati bolezen, ki jo imenujemo rjavenje bukovih listov. Poškodbe zaradi glive Apiognomonia errabunda so se pojavile sekundarno vendar domnevamo, da poškodbe bukovih listov ne bi bile tako obsežne, če ne bi bilo prisotno tudi patogeno delo- vanje omenjene glive. Rjavenje bukovih listov smo zabeležili na južnem delu Snežnika (slika 3). Poškodovanost bukve se je pojavila na površini 1812 ha na nadmorski višini od 970-1570 m. Intenziteta poškodb je bila močna, tj. okoli 50 \% dreves bukev je imelo skoraj vse listje rjavo (slika 4). Poškodovanost bukve zaradi poznega pomladanskega mraza so opazovali tudi ponekod drugod po Sloveniji na nadmorskih višinah nad $800 \mathrm{~m}$.

Rjavenje bukovih listov zaradi glive Apiognomonia errabunda spoznamo po nepravilno razpotegnjenih, zobčastih rjavih nekrotičnih pegah, ki ležijo posamično na listni ploskvi in večinoma ob robu lista (Maček, 2008; slika 5 in 6). Podobne nekrotične pege povzroča bukov rilčkar skakač (Rhynchaenus fagi Linnaeus, 1758). Oba pojava razlikujemo po tem, da ličinka bukovega rilčkarja skakača dolbe v listu rove, ki tečejo od glavne žile do rjave nepravilne pege na robu lista. Gliva Apiognomonia. errabunda oblikuje v odmrlem listnem tkivu drobcena nespolna trosišča, v katerih so številni brezbarvni, enocelični, podolgovato-jajčasti do eliptični 9-13 × 4-6 $\mu \mathrm{m}$ veliki konidiji. Za nespolna trosišča se uporablja ime Discula umbrinella. Spolna trosišča (teleomorf Apiognomonia errabunda) nastanejo naslednjo pomlad na listih, ki ležijo na tleh.

Ukrepanje v primeru rjavenja bukovega listja, ki ga povzroča Apiognomonia errabunda, ni potrebno, saj bo bukev naslednjo leto predvidoma normalno odgnala in ozelenela.

Rjavenje bukovih listov se je v Sloveniji pojavilo že večkrat: leta 1987 v okolici Rogaške Slatine, leta 1996 na Gorjancih, leta 2006 na Smrekovcu (Ogris, 2006). V primeru Gorjancev in Smrekovca je bolezen induciral pozen pomladanski mraz, v primeru Rogaške Slatine pa so se poškodbe pojavile v višinskem pasu ok. $200 \mathrm{~m}$ v sredini pobočja in je bolezen induciral neznan stresni dejavnik. Poleg tega lahko rjavenje bukovih listov spodbudi tudi velika bukova listna hržica (Mikiola fagi Hartig, 1839) in mala bukova listna hržica (Hartigiola annulipes Hartig, 1839).

\section{Viri}

Cegnar T. 2012. Podnebne razmere v maju 2012. Naše okolje, 19 (5): 3-22

Maček J. 2008. Gozdna fitopatologija. Ljubljana, Zavod za gozdove Slovenije, Zveza gozdarskih društev Slovenije - Gozdarska založba: 448 str.

Meteorološki arhiv. Urad za meteorologijo, Agencija Republike Slovenije za okolje. Spletno mesto: http://meteo.arso.gov.si/met/sl/app/webmet/ (13. 7. 2012)

Ogris N. 2006. Rjavenje bukovih listov na Smrekovcu v letu 2006. Ljubljana, Gozdarski inštitut Slovenije, Poročevalska, prognostično-diagnostična služba za gozdove: 7 str.

Zelo močna ohladitev z 12. na 13. maj 2012. Urad za meteorologijo, Agencija Republike Slovenije za okolje. Spletno mesto: http://www.meteo.si/uploads/probase/www/climate/text/sl/weather _events/ohladitev_12-13maj12.pdf (13. 7. 2012) 
${ }^{1}$ Gozdarski inštitut Slovenije, Večna pot 2, 1000 Ljubljana; ${ }^{2}$ Zavod za gozdove Slovenije, Območna enota Postojna, Vojkova 9, 6230 Postojna

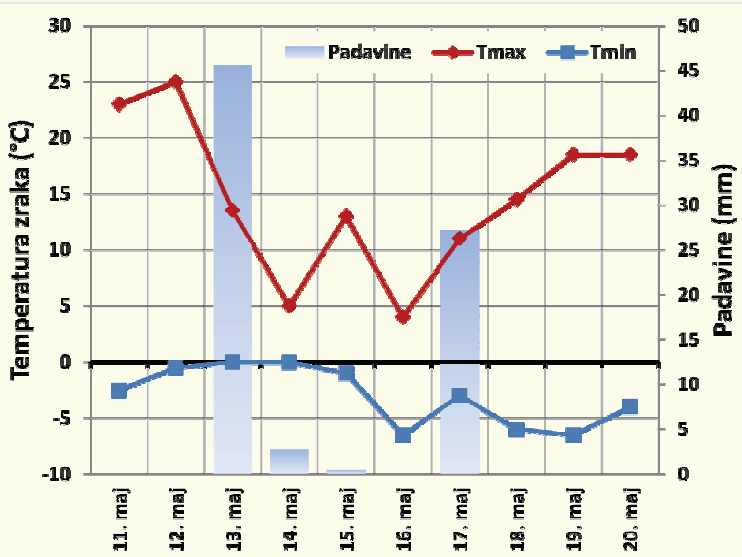

Slika 1: Najvišje (Tmax) in najnižje (Tmin) dnevne temperature zraka v Veliki Padežnici (1127 m) in 24-urne količine padavin v vasi Babno Polje (754 m) v 2. dekadi maja 2012 (Slovenski meteorološki forum, 2012; Meteorološki arhiv ARSO, 2012)

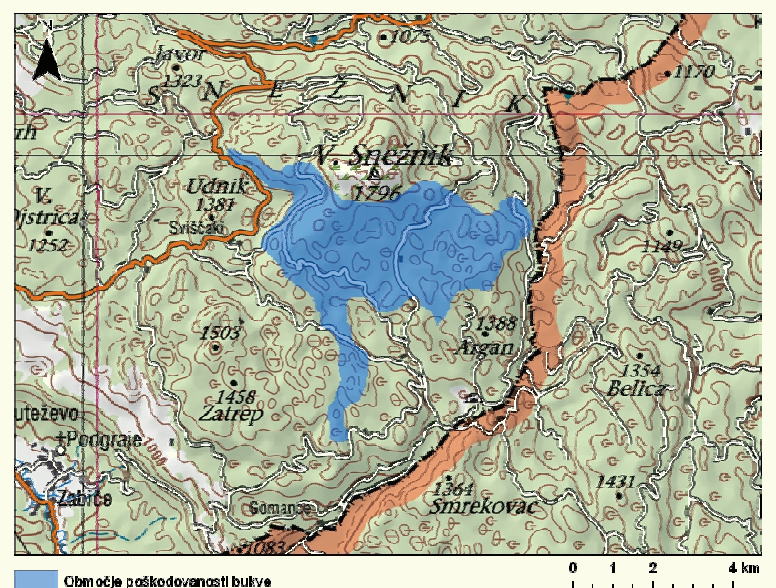

Slika 3: Območje poškodovanosti bukve v okolici Snežnika

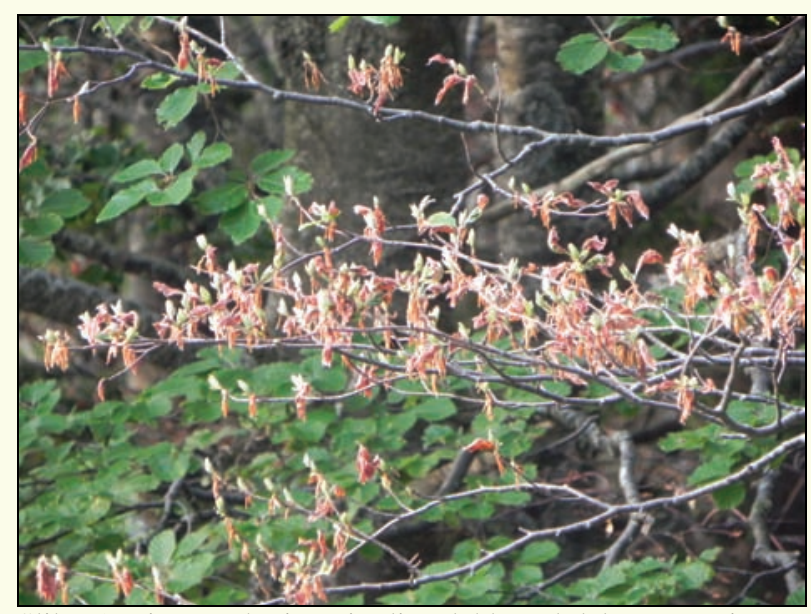

Slika 5: Rjave, suhe in zvite liste lahko od daleč zamenjamo za poškodbe zaradi bukovega rilčkarja skakača (foto. Iztok Sinjur). *nikica.ogris@gozdis.si

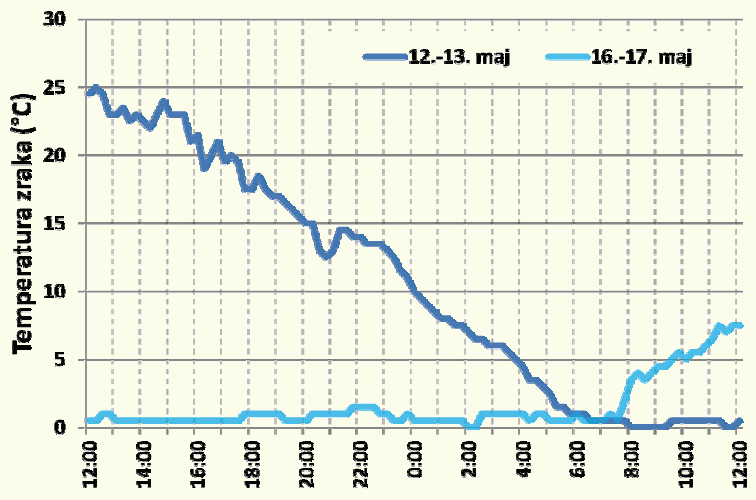

Slika 2: Potek dnevne temperature zraka v Veliki Padežnici $(1127 \mathrm{~m}) \mathrm{v}$ času dveh vremenskih poslabšanj 12.-13. 5. 2012 in 16.-17. 5. 2012 (Slovenski meteorološki forum, 2012)

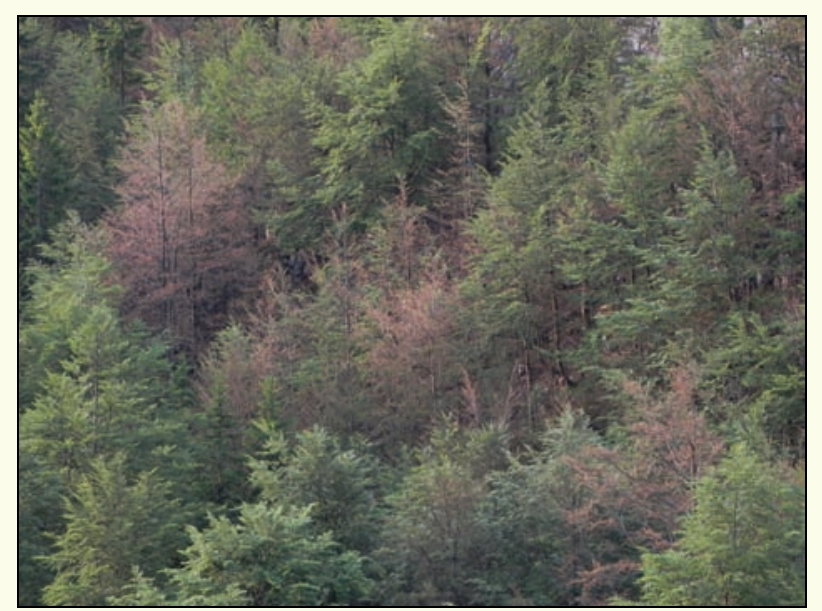

Slika 4: Posamezne bukve na Snežniku so imele poškodovano celo krošnjo (foto. Iztok Sinjur).

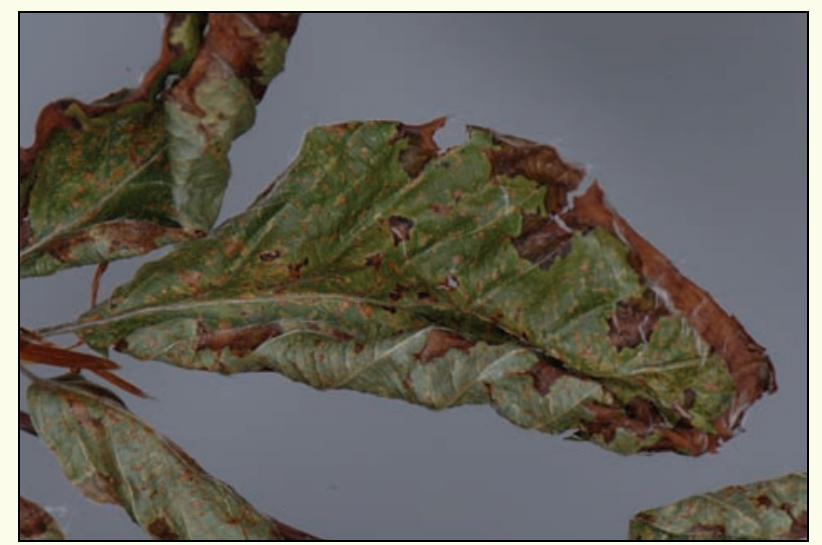

Slika 6: Simptomi rjavenja bukovih listov, ki ga povzroča gliva Apiognomonia errabunda: zobčaste, nekrotične, rjave pege se pojavljajo večinoma na robu, lahko pa tudi na drugih delih lista. Pege se lahko združujejo. Listi se začnejo gubati, zvijati, sušiti in posledično lahko prezgodaj odpadejo (foto. Nikica Ogris). 